\title{
Pengembangan Soal untuk Mengukur Kemampuan Berpikir Tingkat Tinggi pada Materi Peluang Tingkat SMP
}

\author{
Resti Yolanda ${ }^{1}$, Dedy Juliandri Panjaitan ${ }^{2}$ \\ ${ }^{1,2}$ Prodi Pendidikan Matematika, Fakultas Keguruan dan Ilmu Pendidikan, Universitas Muslim Nusantara Al-Washliyah \\ Medan Jl. Garu II A, Kec. Medan Amplas, Kota Medan, Sumatera Utara \\ restiyolandaaprilia33@gmail.com
}

\begin{abstract}
This question development research aims to measure the high-level thinking skills of junior high school students on opportunity material through question development. The development of questions is very necessary so that students can answer questions that require a process of reasoning and critical thinking so that they do not only rely on their memory. The population in this study were students of the Sinar Harapan Beringin Private Junior High School with the subject of the trial before the field being students of class $8 \mathrm{~A}-2$ and the subject of field trials being students of class $8 \mathrm{~A}-4$. The method used in this research is development research using a research model from Baker and Schutz, the data collection instrument used in this research is to use a written test in the form of questions. Based on the validation sheet that has been validated by several experts in their field, it is stated that the questions used are valid and can be used in the field. So, it is hoped that every student has high-level thinking skills in order to be able to solve problems in the form of reasoning or critical and creative thinking questions.
\end{abstract}

Keywords: Question development, High Level Thinking Ability, Opportunity, Junior High School, Reasoning

\begin{abstract}
Abstrak
Penelitian pengembangan soal ini bertujuan untuk mengukur kemampuan berpikir tingkat tinggi siswa Tingkat SMP pada materi peluang melalui pengembangan soal. Pengembangan soal sangat diperlukan agar siswa dapat menjawab soal-soal yang sifatnya membutuhkan proses bernalar dan berpikir kritis sehingga tdak hanya mengandalkan daya ingatnya saja. Populasi pada penelitian ini yaitu siswa SMP Swasta Sinar Harapan Beringin dengan subjek uji coba sebelum kelapangan adalah siswa kelas 8A-2 dan subjek uji coba lapangan siswa kelas 8A4. Metode yang digunakan dalam penelitian ini adalah penelitian pengembangan dengan menggunakan model penelitian dari Baker and Schutz, instrument pengumpulan data yang digunakan dalam penelitian ini adalah menggunakan tes tertulis berupa soal. Berdasarkan lembar validasi yang telah divalidkan oleh beberapa orang ahli dibidangnya menyatakan bahwa soal yang digunakan sudah valid dan dapat dipergunakan dilapangan. Sehingga diharapkan setiap siswa memiliki kemampuan berpikir tingkat tinggi agar dapat menyelesaikan soal-soal dalam bentuk penelaran atau soal-soal berpikir kritis dan kreatif.
\end{abstract}

Kata kunci: Pengembangan soal, Kemampuan Berpikir Tingkat Tinggi, Peluang, SMP, Bernalar

Copyright (c) 2021 Resti Yolanda, Dedy Juliandri Panjaitan

$\triangle$ Corresponding author: Resti Yolanda

Email Address: restiyolandaaprilia33@gmail.com (Jl. Pantai Labu Dsn 1 Barat, Sumatera Utara, Indonesia)

Received 07 June 2021, Accepted 12 July 2021, Published 11 August 2021

\section{PENDAHULUAN}

Kemampuan berpikir tingkat tinggi adalah suatu proses dimana seorang siswa mampu menyelesaikan suatu permasalahan khususnya masalah matematika dengan menggunakan proses bernalar, berpikir kritis dan kreatif, sehingga siswa tidak hanya mengandalkan daya ingatnya saja atau hanya terfokus pada rumus-rumus matematika yang sudah tersedia (Mulyana, n.d.). Kemampuan berpikir tingkat tinggi merupakan salah satu hal yang penting dimiliki oleh masing-masing peserta didik, dimana harapannya siswa mampu menyelesaikan masalah matematika dengan menggunakan proses bernalar (Aningsih, 2018). Siswa yang mempunyai kemampuan berpikir tingkat tinggi biasanya cenderung berpikir kritis karena tidak hanya mengandalkan kemampuan mengingat saja tetapi juga mengandalkan kemampuan berpikir yang kritis dan kreatif. Siswa yang memiliki kemampuan ini ketika 
diberikan soal yang proses pengerjaannya tidak terkait dengan mengingat rumus maka siswa tersebut tidak akan mengalami kesulitan menjawabnya, sebab ia mampu menalar apa yang diminta dari soal tersebut.

Seiring dengan berkembangnya dunia pendidikan di Indonesia, guru-guru dituntut harus bisa memberikan pembelajaran yang kretif sehingga guru mampu memaksimalkan potensi yang dimiliki oleh peserta didik (Arnadh, n.d.). Guru sebagai fasilitator dalam kelas diharapkan bisa menganalisis kebutuhan peserta didiknya dan memfasilitasi belajar sesuai dengan karakter peserta didik. Untuk itu, tenaga pendidik diharapkan dapat mengembangkan suatu produk pembelajaran yang mempunyai nilai tambah dalam memaksimalkan potensi yang ada pada masing-masing peserta didik tersebut (Yuriniky, 2016).

Untuk itu pentingnya guru mengubah konsep soal-soal yang akan diberikan kepada peserta didik agar, peserta didik tidak hanya terfokus atau mengandalkan pada daya ingat yang dimilikinya saja, karena soal-soal yang penyelesaiannya membutuhkan penalaran dan analisis dapat meningkatkan kemampuan berpikir tingkat tinggi, sehingga masing-masing siswa dapat dilatih dan terbiasa untuk menjawab soal-soal yang bentuknya menggunakan penalaran dalam proses memecahkan suatu permasalahan (Tegeh et al., 2014). Menurut (Putri, 2019) dalam Model penyusunan soal HOTs menyatakan bahwa hasil studi internasional PISA menunjukan bahwa prestasi literasi membaca, literasi matematika serta literasi sains yang dicapai oleh peserta didik diIndonesia tergolong sangat rendah sehingga dilakukan standar penilaian pada Kurikulum 2013.

Hasil PISA (Kurniati et al., 2016) menunjukan bahwa secara keseluruhan kemampuan yang dimiliki peserta didik Indonesia sangat rendah dalam: 1) memahami informasi yang akurat 2) teori, analisis serta pemecahan masalah 3) pemakaian alat, prosedur dan juga pemecahan masalah 4) melakukan investigasi, penyempurnaan standar penilaian pada kurikulum 2013 dirasa mampu untuk meningkatkan kemampuan pemecahan masalah, menganalisis dan kreatif, dan membangun kemandirian peserta didik dalam menyelesaikan masalah matematika. Kegiatan yang meningkatkan kemampuan-kemampuan tersebut merupakan salah satu kegiatan yang juga dapat meningkatkan kemampuan berpikir tingkat tinggi.

\section{METODE}

\section{Subjek, Objek dan Waktu Penelitian}

Subjek pada penelitian pengembangan ini adalah siswa SMP Swasta Sinar Harapan Beringin kelas 8A-4 sedangkan untuk uji coba produk sebelum digunakan kelapangan menggunakan non subjek diluar subjek uji coba kelapangan. Objek penelitian ini adalah seluruhan proses dan hasil penelitian pengembangan soal untuk mengukur kemampuan berpikir tingkat tinggi pada materi peluang tingkat SMP. Waktu yang digunakan peneliti untuk penelitian ini dilaksanakan sejak tanggal dikeluarkannya izin penelitian dalam kurun waktu kurang lebih 1 bulan 1 minggu, 1 minggu pengumpulan data di 
lapangan dan 1 bulan lagi berupa pengelolahan data baik penyajian dalam bentuk skripsi dan proses bimbingan secara langsung.

\section{Metode dan Prosedur Penelitian}

Penelitian pengembangan ini menggunakan metode penelitian pengembangan dari Baker and Schutz yang dibagi menjadi beberapa tahap yaitu :1) Perumusan, 2) Tahap Spesifikasi Langkah 3) Tahap uji coba soal, 4) Tahap pengembangan produk, 5) Tahap uji coba produk, 6) Tahap revisi produk, 7) Tahap analisis untuk pemanfaatan. Desain yang digunakan dalam penelitian ini menggunakan alur desain yang berupa Formative Evaluation (Lewy, 2013) Berikut ini akan dijelaskan alur desain Formative Evaluation.

\section{Tahap Persiapan (Preliminary)}

Pada tahap ini peneliti menentukan tempat, subjek penelitian serta mengatur jadwal penelitian. Peneliti juga menganalisis kurikulum pendidikan yang digunakan disekolah, dan pembuatan materi pembelajaran yang akan dilakukan pengembangan serta beberapa literature tentang penelitian pengembangan yang pernah dibuat kemudian dihubungkan dengan penelitian yang akan direncanakan untuk dijadikan draf prototype awal.

\section{Tahap Self Evaluation}

1. Analisis

Pada tahap ini salah satu langkah awal dalam penelitian pengembangan. Pada langkah ini peneliti akan menganalisis siswa, menganalisis materi, KTSP/SMP harus sesuai dengan kurikulum yang digunakan disekolah dan tuntutan pendidikan.

2. Desain

Pada tahap Desain, peneliti merancang produk berupa soal yang digunakan untuk mengukur kemampuan berpikir tingkat tinggi pada materi peluang. Desain produk ini sebagai prototype. Masing-masing fokus pada 3 karakter yaitu: konten, konstruk dan bahasa

Tabel 1. Karakteristik yang menjadi fokus Prototype

\begin{tabular}{|c|c|}
\hline Konten & $\begin{array}{l}\text { Soal-soal tes untuk mengukurkemampuan berpikir kritis } \\
\text { sesuai dengan: } \\
\text { 1. Kompetensi Dasar (KD) } \\
\text { 2. Indikator } \\
\text { 3. Tujuan Pembelajaran }\end{array}$ \\
\hline Konstruk & $\begin{array}{l}\text { Soal sesuai dengan teori yang mendukung dengan kriteria: } \\
\text { 1. Mengembangkan kemampuan menganalisis, } \\
\text { mengevaluasi dan mengkreasi serta proses bernalar } \\
\text { seorang peserta didik } \\
\text { 2. Banyak mengandung konsep } \\
\text { 3. Sesuai dengan level siswa tingkat Sekolah Menengah } \\
\text { Pertama } \\
\text { 4. Mengundang pengembangan konsep lebih berlanjut }\end{array}$ \\
\hline Bahasa & $\begin{array}{l}\text { 1. Sesuai dengan Ejaan Yang Disempurnakan } \\
\text { 2. Bahasa yang digunakan tidak berbelit } \\
\text { 3. Tidak mengandung arti ganda sehingga siswa mudah } \\
\text { dalam memahami soal }\end{array}$ \\
\hline
\end{tabular}




\begin{tabular}{|l|ll|}
\hline & $\begin{array}{l}\text { 4. } \\
\text { 5. }\end{array}$ & $\begin{array}{l}\text { Mengasa pertanyaan dan jawaban harus jelas } \\
\text { peserta didik }\end{array}$ \\
\hline
\end{tabular}

Ketiga karakteristik diatas telah divalidasi oleh beberapa orang pakar. Langkah ini disebut Teknik triangulasi.

\section{Tahap Validasi, Evaluasi, dan Revisi}

Pada langkah-langkah ini, soal yang telah dibuat sebelumnya akan diperiksa. Ada 3 langkah uji coba yaitu:

1. Pakar dan seorang Siswa

Hasil desain pada prototype pertama yang dikembangkan atas dasar evaluasi diberikan oleh pakar dan seorang siswa secara pararel. Dari hasil evaluasi pakar dan seorang siswa dijadikan bahan revisi. Pakar juga disebut validator (orang yang memvalidkan). Soal yang sebelumnya sudah dibuat akan diamati, dinilai serta diperiksa oleh pakar. Pakar akan menelaah konten, konstruk serta bahasa dari setiap prototype. Pada tahap ini, validator memberikan tanggapan dan saran terhadap desain yang telah dibuat sebelumnya, saran yang telah diberi validator ditulis pada lembar validasi sebagai bahan revisi dan menyatakan bahwa soal-soal untuk mengukur kemampuan berpikir tingkat tinggi tersebut dinyatakan telah valid dan dapat digunakan dilapangan. Pada langkah ini, peneliti menjadikan seorang siswa sebagai uji coba, kritik dan saran yang diberikan siswa akan dijadikan bahan untuk merevisi desain produk yang telah dibuat.

2. Kelompok Kecil

Hasil revisi dari pakar serta komentar serta kritik dan saran yang diberikan siswa saat uji coba pada prototype awal dijadikan dasar dalam revisi desain prototype berikutnya. Kemudian hasilnya diuji coba pada kelompok kecil ( 5 orang siswa non subjek penelitian). Pada tahap ini akan diminta 5 orang siswa tingkat SMP untuk menyelesaikan soal yang telah didesain sebelumnya.

3. Uji Lapangan

Kritik serta saran dan hasil uji coba yang telah dilakukan pada prototype kedua dijadikan dasar untuk merevisi desain prototype berikutnya. Kemudian hasilnya diuji cobakan ke subjek penelitian dalam hal ini sebagai Uji Lapangan. Produk yang telah direvisi kemudian di uji coba kepada peserta didik setingkat SMP yang menjadi subjek penelitian ini. Kriteria keberhasilan dari penelitian ini adalah didapat produk yang berupa soal yang dapat mengukur kemampuan berpikir tingkat tinggi pada materi peluang.

\section{Instrumen dan teknik pengumpulan data}

Berdasarkan prosedur penelitian yang telah diatas, maka teknik dan instrumen pengumpulan data yang digunakan dalam penelitian ini adalah dengan menggunakan tes tertulis yaitu berupa soal-soal yang telah dihasilkan. Tes digunakan untuk memperoleh data tentang keefektifan dari soal-soal yang 
telah divalidkan untuk mengukur kemampuan berpikir tingkat tinggi. Tes berupa soal bentuk essay yang mengarah pada indikator kemampuan berpikir tingkat tinggi.

\section{HASIL DAN DISKUSI}

Penelitian ini dilakukan pada semester ganjil tahun ajaran 2020/2021. Pada tahap ini peneliti memberikan tes berupa soal-soal essay atau uraian kepada 5 siswa kelas 8A-2 sebagai subjek uji coba sebelum kelapangan dan subjek ini diluar dari subjek uji coba dilapangan. Sedangkan subjek penelitian dilapangan yaitu siswa kelas 8A-4 yang berjumlah 32 siswa, semua subjek baik siswa yang menjadi subjek uji coba sebelum kelapangan maupun subjek uji coba lapangan merupakan siswa SMA Swasta Sinar Harapan Beringin.

Penelitian ini bertujuan untuk mengetahui apakah dengan mengubah konsep soal, dari soal yang awalnya hanya mengandalkan daya ingat saja berubah menjadi konsep soal yang membutuhkan kemampuan berpikir kritis dan bernalar agar dapat meningkatkan kemampuan berpikir tingkat tinggi pada siswa tingkat SMP. Karena penelitian ini dilaksanakan pada saat pandemi covid-19 maka penelitiannya juga dibatasi sehingga peneliti membagi siswa uji coba lapangan sebanyak tiga gelombang dan siswa uji coba sebelum kelapangan 1 gelombang sehingga total gelombang yang dibuat oleh peneliti sebanyak empat gelombang.

Karena penelitian ini merupakan penelitian pengembangan maka peneliti hanya membagikan produk peneliti yang telah dibuat dan divalidasi oleh beberapa orang ahli di bidangnya sehingga peneliti tidak memberikan pembelajaran kepada siswa baik siswa uji coba sebelum kelapangan maupun siswa uji coba lapangan.

\section{Hasil tahap uji coba sebelum kelapangan}

Berdasarkan hasil tes uji coba sebelum kelapangan pada lima orang siswa SMP Swasta Sinar Harapan kelas 8A-2 siswa diberikan waktu pengerjaan sesuai dengan tingkat kesukaran soal tersebut. Hasil dari uji coba small grup (kelima siswa) dan expert review (pakar) maka soal-soal untuk mengukur kemampuan berpikir tingkat tinggi direvisi kembali.

Tabel 2. Saran Validator Terhadap Produk yang dihasilkan

\begin{tabular}{|l|ll|}
\hline \multicolumn{2}{|c|}{ Saran dan komentar Validator } & \multicolumn{1}{c|}{ Keputusan Revisi } \\
\hline $\begin{array}{l}\text { 1. Pada bagian soal yang penyelesaiannya } \\
\text { masih menggunakan rumus harus diganti }\end{array}$ & 1. $\begin{array}{l}\text { Soal-soal yang penyelesaianya masih } \\
\text { menggunakan rumus diganti mejadi soal-soal } \\
\text { yedalam bentuk soal penalaran }\end{array}$ \\
$\begin{array}{l}\text { 2. } \begin{array}{l}\text { kemudian buat beberapa soal yang } \\
\text { mengandung argument agar siswa } \\
\text { semakin berpikir lebih kritis lagi dalam } \\
\text { menjawab soal tersebut. }\end{array} \\
\text { 2. }\end{array}$ & $\begin{array}{l}\text { Beberapa soal sudah diberikan pertanyaan } \\
\text { yang mengandung argument agar } \\
\text { kemampuan berpikir siswa lebih meningkat. }\end{array}$ \\
\hline
\end{tabular}




\section{Hasil Tahap Uji Coba Lapangan}

Soal-soal yang sebelumnya telah direvisi setelah tahap uji coba dalam skala kecil kemudian diperiksa kembali oleh pakar untuk memastikan soal tersebut sudah layak diuji cobakan ke lapanganatau belum, Setelah dinyatakan valid oleh validator maka dapat digunakan ke lapangan. Pengumpulan data dilakukan secara bertahap sesuai dengan gelombang yang sudah ditetapkan sebelumnya, yaitu setiap siswa hanya mempunyai waktu 60 menit untuk menjawab 13 soal yang telah diberikan. Waktu tersebut berlaku untuk semua gelombang, setelah waktunya selesai maka semua siswa harus mengumpulkan kembali lembar jawaban kepada peneliti sedangkan untuk lembar jawaban diperbolehkan untuk dibawa pulang agar dapat dipelajari kembali. Dari hasil data yang diperoleh dilapangan maka data tersebut diperiksa dan diubah kedalam data berbentuk angka agar dapat memudahkan dalam pengkategorian tingkat kemampuan berpikir tingkat tinggi. Adapun presentase hasil dilapangan dapat dilihat dari tabel 3 dibawah ini.

Tabel 3. skor rata-rata kemampuan berpikir tingkat tinggi siswa

\begin{tabular}{|c|c|c|c|}
\hline Rentang Skor & Jumlah Siswa & Presentase (\%) & Kategori \\
\hline $76-100$ & 2 & $6,25 \%$ & Sangat Baik \\
\hline $51-75$ & 15 & $46,875 \%$ & Baik \\
\hline $26-50$ & 10 & $31,25 \%$ & Cukup \\
\hline $1-25$ & 5 & $15,625 \%$ & Kurang \\
\hline Jumlah & 32 siswa & 100 & \\
\hline Rata-rata & & 54,90 & Baik \\
\hline
\end{tabular}

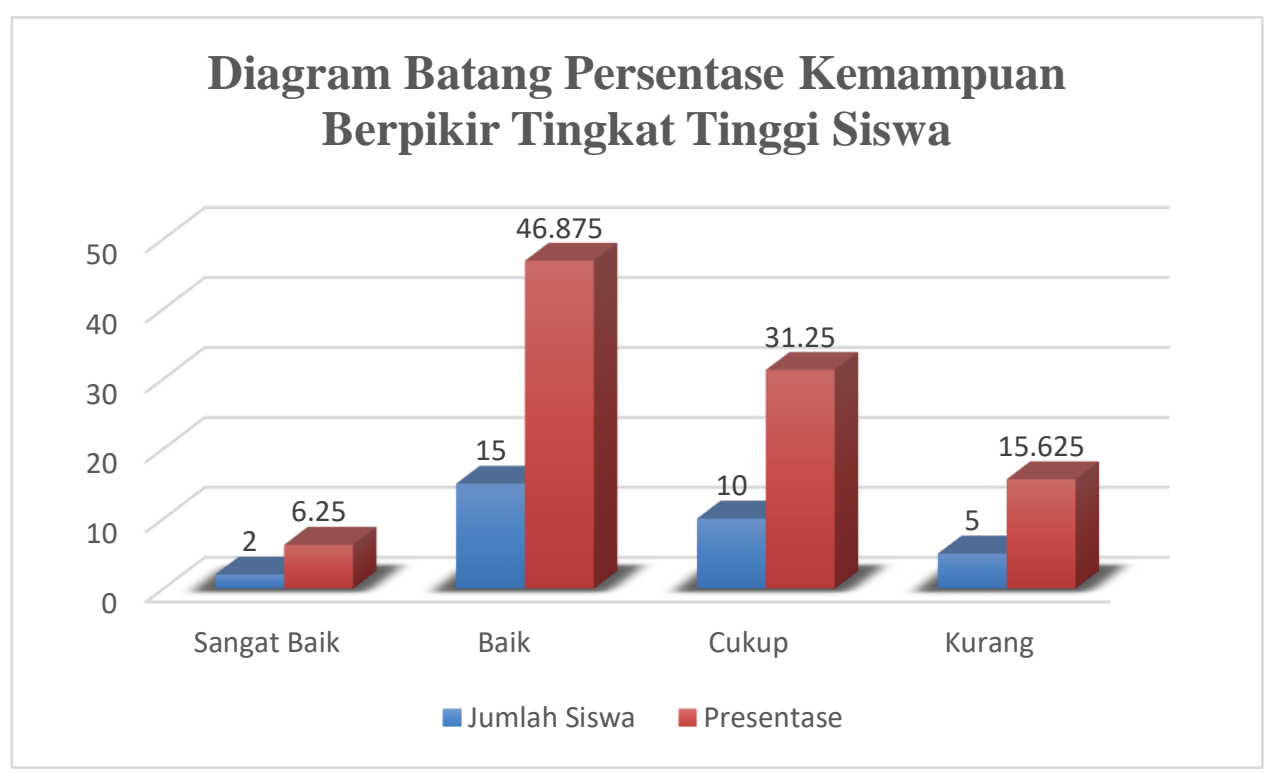

Gambar 1. Persentase Kemampuan Berpikir Tingkat Tinggi Siswa

Dari data diatas untuk mengukur kemampuan berpikir tingkat tinggi siswa pada materi peluang tingkat SMP diketahui bahwa 2 orang siswa $(6,25 \%)$ yang termasuk kedalam kategori mempunyai kemampuan berpikir tingkat tinggi yang sangat baik, kemudian ada 15 orang siswa $(46,875 \%)$ yang termasuk kedalam kategori memiliki kemampuan berpikir tingkat tinggi yang baik, ada 10 orang siswa 
Pengembangan Soal untuk Mengukur Kemampuan Berpikir Tingkat Tinggi pada Materi Peluang Tingkat SMP, Resti Yolanda ${ }^{l}$, Dedy Juliandri Panjaitan

$(31,25 \%)$ yang termasuk kedalam kategori mempunyai kemampuan berpikir tingkat tinggi yang cukup serta 5 orang siswa $(15,625 \%)$ yang termasuk kedalam kategori memiliki kemampuan berpikir tingkat tinggi yang kurang.Dari hasil tes dilapangan diketahui bahwa kemampuan siswa dalam menganalisis soal serta kemampuan siswa dalam bernalar sudah cukup baik, terbukti dari hasil tes siswa yang menunjukan bahwa nilai yang diperoleh rata-rata kelas masuk dalam kategori kemampuan berpikir tingkat tinggi yang baik.

\section{Diskusi}

\section{KESIMPULAN}

Berdasarkan data penelitian serta hasil tes dilapangan terhadap pengembangan soal untuk mengukur kemampuan berpikir tingkat tinggi pada materi peluang tingkat SMP, maka peneliti membuat kesimpulan yaitu : ketika siswa diberikan soal yang proses menjawabnya hanya mengandalkan daya ingatnya saja maka kemampuan bernalar serta menganalisis soal yang dimiliki siswa sangat rendah, karena siswa hanya dituntut untuk mengingat saja bukan dituntut untuk menganalis, bernalar bahkan berpikir kritis untuk menyelesaikan suatu permasalahan soal matematika.

Kemampuan berpikir tingkat tinggi pada siswa dapat diasah secara perlahan dengan cara guru mengubah konsep-konsep soal yang hanya mengandalkan daya ingat siswa saja menjadi konsep soalsoal yang penyelesaiannya melibatkan penalaran bahkan sampai berpikir kritis. Apabila guru terbiasa memberikan bentuk soal yang berpikir kritis maka kemampuan berpikir tingkat tinggi siswa sedikit demi sedikit akan terasa dengan sendirinya seiring dengan seringnya guru memberikan soal dengan bentuk tersebut. Jika siswa sudah terbiasa mejawab soal-soal kemampuan berpikir tingkat tinggi, maka ketika siswa menghadapi Ujian Nasional (UN) bahkan ujian seleksi ke SMA unggulan akan semakin mudah siswa menjawabnya, karena bentuk soal kemampuan berpikir tingkat tinggi sering dijumpai di soal-soal UN atau soal test seleksi unggulan.

Pengembangan soal pada materi peluang ini terbukti dapat meningkatkan kemampuan berpikit tingkat tinggi pada siswa. Terbukti dari produk yang berupa soal yang dikembangkan dikategorikan valid, dinyatakan valid setelah melewati beberapa revisian dari para pakar baik dari pakar pendidikan sampai pakar khusus bidang kemampuan berpikir tingkat tinggi sudah menyatakan produk soal ini valid baik dari segi isi, materi, bahkan dari segi bahasa yang digunakan pada soal dan dapat di ujikan langsung ke lapangan. Berdasarkan hasil tes yang dilakukan dilapangan diperoleh pengembangan soal ini memilki efektivitas yang baik untuk meningkatkan kemampuan berpikir tingkat tinggi siswa karena dilihat dari hasil rata-rata nilai siswa yaitu sebesar 54,90 yang masuk kedalam kategor imemiliki kemampuan berpikir tingkat tinggi yang baik.

\section{REFERENSI}

Aningsih, A. (2018). Kemampuan berpikir tingkat tinggi pada pendidikan agama islam siswa kelas $X$

Smk Muhammadiyah 1 Purwokerto ditinjau dari prestasi belajar. 5-24.
http://repository.ump.ac.id/7373/


Arnadh. (n.d.). 5 Alasan Kemampuan Berpikir Penting Banget dalam Dunia Pendidikan. https://www.idntimes.com/life/education/uswatun-niswi/alasan-kemampuan-berpikir-pentingbanget-dalam-dunia-pendidikan-exp-c1c2/1

Kurniati, D., Harimukti, R., \& Jamil, N. A. (2016). Kemampuan berpikir tingkat tinggi siswa SMP di Kabupaten Jember dalam menyelesaikan soal berstandar PISA. Jurnal Penelitian Dan Evaluasi Pendidikan, 20(2), 142-155. https://doi.org/10.21831/pep.v20i2.8058

Lewy, L. (2013). Pengembangan Soal Untuk Mengukur Kemampuan Berpikir Tingkat Tinggi Pokok Bahasan Barisan Dan Deret Bilangan Di Kelas Ix Akselerasi Smp Xaverius Maria Palembang. Jurnal Pendidikan Matematika, 5(1). https://doi.org/10.22342/jpm.5.1.821.

Mulyana, A. (n.d.). PENELITIAN PENGEMBANGAN (RESEARCH AND DEVELOPMENT ) $\begin{array}{llll}\text { Pengertian, } & \text { Tujuan } & \text { Langkah-langkah }\end{array}$ https://ainamulyana.blogspot.com/2016/04/penelitian-pengembangan-research-and.html

Putri, V. N. A. (2019). Analisis High Order Thingking Skill (HOTS) calon guru pada permasalahan turunan dan penerapannya (Studi kasus: Sembilan mahasiswa pendidikan matematika Universitas Sanata Dharma angkatan 2015). Universitas Sanata Dharma, 53(9).

Tegeh, I., Jampel, I., \& Pudjawan, K. (2014). Model Penelitian Pengembangan. Graha Ilmu.

Yuriniky. (2016). HAKIKAT MATEMATIKA, PEMBELAJARAN MATEMATIKA DAN TEORI BELAJAR. https://yuriniky.wordpress.com/2016/03/21/hakikat-matematika-pembelajaranmatematika-dan-teori-belajar/. 